\title{
Editorial
}

\section{Full speed ahead in stormy weather}

International Journal of Disclosure and Governance (2008) 5, 1-3.

doi:10.1057/palgrave.jdg.2050078

My last editorial was on the then-emerging subprime mortgage-driven liquidity crisis, and when I wrote it I wondered whether by the time it saw print it would seem unduly alarmist. Unfortunately, if anything, world financial markets seem to be facing a more systematic and ingrained set of problems than seemed apparent even at the time. While the immediate sense of panic of a few months ago has subsided, there is as yet no return in market confidence. As a consequence, the likelihood that the credit crisis will affect the real economy is increasing, especially when combined with the dramatic downturn in the housing sector in the United States, sharp increases in foreclosures and oil approaching $\$ 100$ a barrel.

Moreover, the forced resignations of the CEOs of Citicorp and Merrill Lynch have exacerbated rather than allayed concerns about the exposure of leading banks to increasingly toxic debt. When markets focus on 'who's next?' and 'what's next?' instead of wheeling and dealing, then there is a way to go before business as usual can resume. A real problem is the growing consensus that the financial engineers on Wall Street and in the City of London simply screwed up the mathematical models that they used to support securitisation and the other complex strategies that now dominate trading - and that is no academic matter considering that a very large proportion of the profits of even non-financial firms comes from financial transactions.

The valuation of such securities is based on the assumption that they can be sold when necessary, such as when the underlying asset is falling in value. But astonishingly, the financial engineers never took into account the fact that with instruments becoming similar to each other (hardly surprising as the best and the brightest jumped from one firm to another) everyone would want to sell at the first indication of trouble and no one would want to buy. Worse, with no liquid market for these synthetic securities, it has become difficult to assess what these products are now worth, which creates a self-fulfilling circle of doubt about the security of bank portfolios.

While there are many lessons from this continuing debacle, one in particular is glaring: the need for more disclosure on a wide variety of fronts by firms involved in these high stakes financial trades. Disclosures needed include those on the role of the rating agencies and their conflicts of interest; the actual extent of exposure to various classes of securities, the magnitude of losses that are possible under various trading strategies and any compensating controls that the board of directors has put in place to mitigate such risks (noting that Morgan Stanley lost $\$ 3.7 \mathrm{bn}$ in a single subprime mortgage gamble). Disclosure may not be sufficient to overcome wishful thinking or flawed models. But they will at least provide investors with a better idea as to the actual position of firms, and help avoid situations such as being caught by surprise by securitisations that did not transfer risk to the extent that they were assumed to do.

Indeed, when one considers the way in which complex securities were sold to firms and their investors, it is worth recalling the words of famed science fiction writer Arthur C. Clarke, who wrote: 'Any sufficiently advanced 
technology is indistinguishable from magic.' It is indeed magic to believe that risk can somehow not just disappear, but actually be transformed by a process that takes junk bonds and subprime mortgages and makes them into AAA rated securities. Perhaps investors did not pay sufficient attention to the fact that this process was called 'financial alchemy'. The crisis will never be solved until there is sufficient disclosure by many more firms than just the obvious suspects, the large trading banks, about the extent of their exposure to complex financial instruments and the losses they have sustained assuming that they are even aware and able to assess the value at risk.

The fact that disclosure, and its close ally, better governance, has such a critical role to play in the restoration of trust in financial markets would hardly come as a surprise to the readers of this journal. Indeed, the reason it was set up was the belief that capitalism can only thrive in an environment in which there is transparency and accountability between users and providers of capital. Unfortunately, it seems to take a crisis or a recession (both of which we might soon get) to make industry participants accept the reality of the old dictum that sunshine is the best disinfectant, and that disclosure beats the alternative of knee jerk regulation or legal constraints on the workings of markets.

With this setup I am proud to announce that this issue of the journal marks the transition of its editorial leadership from its founder, John Friedland, to a team from Rutgers Business School, headed by me. I am sure that all readers of this journal express their appreciation for the way in which John single-handedly created this journal and made it the international success that it has become. Thanks to that very success, the journal has become too large an enterprise for any one individual to control on their own, which prompts this transition.

The advantages of having the resources of a major research university behind the journal have already been demonstrated by the success of the inaugural International Journal of Disclosure and Governance Conference that was held at
Rutgers Business School in September 2007. Over 100 individuals from business, the accounting profession and academia attended the event, which was sponsored by the Institute of Management Accountants (IMA), the Open Compliance Ethics Group (OGEC) and the Prudential Business Ethics Centre. This issue contains some of the proceedings from the conference, including a rather controversial keynote speech by the CEO of the IMA, Paul Sharman.

This issue is one of the largest that we have ever published and it represents both a recommitment to the mission of the journal and a sign of things to come. The journal is seeing an extraordinary increase in the number of manuscripts being submitted to it, from all around the world. We are also actively commissioning papers covering important topics in the governance area from highly placed individuals in organisations that define today's business environment. That work will be guided by a new editorial board that will be coming on board during the coming year and will provide strategic leadership to me as editor, as well as extending the reach of the journal globally and into critical functional areas in disclosure and governance space.

Many new innovations will flow into the journal as we move forward. One that begins with this issue is the replacement of the abstract for articles by executive summaries placed at the beginning of the issue. Authors are told that the executive summaries have to address the following questions:

1. What is the central takeaway of your article? What important, useful, new or counterintuitive idea does it communicate?

2. Who needs to read your paper? Please note that if the answer to this question is some variant of 'academics/lawyers/managers only', the paper should probably be submitted elsewhere.

3. How can your idea be applied in business today and what value added will it provide (ie, answer the 'so what' question)? 
4. What is the source of your authority? What academic research or professional experience backs up your conclusions?

5. The bottom line: Why should a reader bother reading your article, especially one with a different background from the authors and/or one who will have to invest their time in understanding a methodology they may not be familiar with?

Why the change? Because it is aligning the style of the journal better with its mission. The International Journal of Disclosure and Governance has as its goal the advancement of the theory and practice of corporate governance and transparency. The means of achieving that goal is by providing a forum to which both business professionals and academics contribute equally and provide articles that are equally accessible and insightful to all our readers.

What distinguishes the journal is that its explicit intention is to influence business practice by appealing to a broad and inclusive audience. Hence, whether written by practitioners or academics, articles that it publishes must be accessible to people from varying backgrounds and interests. Inevitably, though, some of those articles will be written in a style that will be unfamiliar to one subset of our readers or another, be it statistics-driven academic research that will challenge our professional readers, or thought pieces from business leaders that academics might consider as speculative. That should not be a concern if an open-minded reader will learn something from these articles that they otherwise would not.

Hence, the executive summaries, which explains the practical impact of the ideas contained in the papers, written in an accessible manner without jargon. The charge to the authors is to encourage readers to consider reading an article that they otherwise would consider off-putting - in short, for the authors to sell their paper to the widest possible audience, and not just restrict it to readers from the same background as themselves.

The introduction of executive summaries is a reaffirmation that despite the change in editorial control, the journal is committed to its central mission of leadership in the creation and dissemination of the best ideas and practice in disclosure and governance globally. In particular, the journal aims to serve as a bridge between the academic and practitioner communities, communities that need to learn from each other and who have a great deal to teach other too despite all too frequently speaking past each other.

I look forward to your comments and your continued participation as your journal begins its new journey. There is a long voyage ahead of us, but as the business climate becomes stormier, the need for this journal surely becomes ever clearer.

\section{Michael Alles} Editor 